\title{
6. The Interpretation of Power Politics: Coral Bell's International Thought
}

\author{
Ian Hall
}

It is fair to say that Coral Bell remained somewhat sceptical about international relations theory throughout her long career. She could, at times, even be scathing about the subfield, calling it 'a very unimpressive growth', a plant that 'ought to be centrepiece and glory of the garden', but which - alas - had 'obstinately refused to put on more than a few inches in height, despite much watering, pruning, tilling, crooning over, and feeding with rare and expensive nutrients'. ${ }^{2}$ She declared herself fully persuaded by Martin Wight's argument about the 'intractability of international experience' and the near-impossibility of theorising about such a challenging domain. ${ }^{3}$ But none of this should distract attention from the fact that Bell had an international theory of her own, albeit one half-buried in her work, and rarely at the surface.

Bell's international theory was an old-fashioned kind, akin to that of the traditionalist realists and liberals of the first generation of theorists, who flourished before the behaviouralist revolution in the social sciences of the 1950s and all that came after. It sought to interpret the beliefs that shape policies and practices in international relations and to explain their evolution in historical perspective, with a particular focus on key agents and the ideas they espoused. She drew inspiration for her approach from many sources, but one was particularly important: her erstwhile mentor at the London School of Economics (LSE), Martin Wight. ${ }^{4}$ She inherited from Wight a profound hostility to scientific approaches to the field and a staunch belief that studying international relations involved, as she put it, a 'meditation on history' ${ }^{5}$ In this, of course, she was not alone - various bits of the so-called 'English School of

\footnotetext{
1 I am very grateful to Desmond Ball, in particular, for asking me to write the chapter and talking to me about aspects of Bell's life and work, as well as to Renée Jeffery, Paul Keal and Brendan Taylor, for the various conversations about this piece.

2 Coral Bell, 'The State of the Discipline: I.R.', Quadrant, vol. 12, no. 1, January-February 1968, p. 82.

3 ibid., p. 82.

4 On Wight's ideas in general, see Ian Hall, The International Thought of Martin Wight, Palgrave, New York, 2006. Bell did graduate work under Wight's direction at the London School of Economics in the early 1950s. He later helped appoint her to the Professorship of International Relations at Sussex, where Wight served as Professor of History and Dean of European Studies from 1961 until his untimely death in 1972.

5 Bell, 'The State of the Discipline', p.83. Wight used the same phrase in unpublished papers. See, for example, 'History and the Study of International Relations', no date, but probably mid-1950s, Wight MS 112, British Library of Political and Economic Sciences, p. 1.
} 
International Relations' have put this argument since Wight suggested it in the 1950s and Hedley Bull popularised it in the 1960s and 1970s. ${ }^{6}$ Bell departed from Wight and from his followers, however, in one important aspect: unlike them, she had no time for what she called the 'metaphysics of history'. ${ }^{7}$

Her attachment to the past and her dislike of the 'metaphysics of history', together with an innate scepticism, helped make Bell a conservative. Her fascination for power-or, rather, for the ways in which power is wielded in international relations - made her a realist, of sorts. But the label 'conservative realist' makes Bell sound theoretically unsophisticated - except to the occasional admirer ${ }^{8}$ - and her international thought was not. So this chapter sets that label aside, not so much because it is inaccurate but because it is unhelpful in the task at hand. It argues instead that Bell advanced what might best be called an agent-centred interpretive theory of international relations. This might not be the most elegant description - and Bell would probably have disliked it - but it is, the chapter contends, the most revealing about her international thought.

\section{Foundations}

Bell came to the study of international relations as many of her generation of British and Australian scholars did, through the study of history, and especially through the work of good history teachers. In a short memoir, she recalled how her interest in the past and its relationship to the present was kindled at both primary school and Sydney Girls High. At the latter, she noted, she was 'encouraged ... to see the world of current events as history just waiting to be written' and asked to write it, producing an essay on the Munich Crisis of 1938 in its immediate aftermath. ${ }^{9}$ Bell nurtured these interests at the University of Sydney, studying history as well as literature, economics and philosophy,

6 On the English school in general, see Tim Dunne, Inventing International Society: A History of the English School, Macmillan, Basingstoke, 1997; and on Bull's views, see especially his 'International Theory: A Case for a Classical Approach', World Politics, vol. 18, no. 3, 1966, pp. 361-377. Richard Devetak rightly acknowledges Bell's close relationship with the early English school in his 'An Australian Outlook on International Affairs? The Evolution of International Relations Theory in Australia', Australian Journal of Politics and History, vol. 55, no. 3, 2009, p. 349.

7 Bell, 'The State of the Discipline', p. 84. For English school ventures into that area, see inter alia Martin Wight, 'The Church, Russia and the West', Ecumenical Review, vol.1, no. 1, 1948, pp. 25-45, Herbert Butterfield, History and Human Relations, Collins, London, 1951; and Peter Savigear, 'International Relations and the Philosophy of History', in Michael Donelan (ed), The Reason of States: A Study in International Political Theory, Allen \& Unwin, London, 1978, pp. 195-205.

8 Robert O'Neill observes that Bell sometimes used this phrase to describe herself, but also finds it unhelpful - see his obituary 'Coral Bell AO 1923-2012: A balanced, independent, realist-minded scholar of world politics', The Interpreter, Lowy Institute for International Policy, 3 October 2012. http://www. lowyinterpreter.org/post/2012/10/03/Coral-Bell-AO-1923-2012-a-balanced-independent-realist-mindedscholar-of-world-politics.aspx (accessed 2 August 2013).

9 Coral Bell, 'A Preoccupation with Armageddon', unpublished memoir, Canberra, 2012, p. 2. 
taking full advantage of a broad curriculum and an impressive faculty, including the great empiricist philosopher, John Anderson, who also taught Hedley Bull. ${ }^{10}$ These studies served Bell well, helping her to secure the position in the Department of External Affairs she held from 1945 to 1951. In turn, her government work provided invaluable - and, if her memoir is any guide, eye-opening ${ }^{11}$ _ experience of the making of foreign policy and the practice of diplomacy.

Bell's enduring interest in the past and her interest in the practices of international relations no doubt predisposed her to Wight, whom she later called 'the chief intellectual influence of my entire life', and his approach to the field. ${ }^{12}$ In 1951, when Bell resigned from External Affairs and applied for graduate studies at the LSE, Wight was a relatively minor figure in the nascent but tiny field of International Relations, and a man with a somewhat unusual background. Born in 1913 into a relatively prosperous middle-class family, Wight read Modern History at Hertford College, Oxford in the tumultuous early 1930s. He won a First but also engaged in university politics, becoming known as a passionate defender of the League of Nations at a time when many were starting to question its efficacy. Wight abandoned that cause soon after leaving Oxford, during the Abyssinian crisis of 1935-36, turning instead to Christian pacifism and the Reverend 'Dick' Sheppard's 'Peace Pledge Union' (PPU). At around the same time, Wight began to further his professional interest in international relations, securing a temporary post at Chatham House, where he worked closely with its Director of Studies, Arnold J Toynbee, the author of the Survey of International Affairs and A Study of History. ${ }^{13}$ After three years or so, Wight moved on again, this time to become a History Master at Haileybury School, but he was forced to give up this post in 1940 after a failed application to register as a conscientious objector. He passed the remainder of the war back at Oxford, working (unhappily) with Margery Perham on British colonial constitutions. In 1945, he escaped Oxford and Perham to travel to the United States and spend a year as The Observer newspaper's United Nations

\footnotetext{
10 On Anderson and Bull, see Renée Jeffery, 'Australian Realism and International Relations: John Anderson and Hedley Bull on Ethics, Religion and Society', International Politics, vol. 45, no. 1, 2008, pp. 52-71.

11 See especially Bell, 'A Preoccupation with Armageddon', pp. 5-10.

12 ibid., p. 13.

13 Arnold J Toynbee, Survey of International Affairs, various vols., Royal Institute of International Affairs and Oxford University Press, London, 1924-58; and A Study of History, 12 vols., Oxford University Press, London, 1934-61.
} 
correspondent. After another brief stint at Chatham House, Wight finally ended up at the LSE, where the idiosyncratic head of the Department of International Relations, Charles Manning, ${ }^{14}$ appointed him to a Readership in 1949. ${ }^{15}$

Wight's early scholarly achievements were few, but what he had published was well-regarded. The highlight was a seventy page pamphlet produced for Chatham House, Power Politics (1946), ${ }^{16}$ which displayed Wight's extraordinary historical range as well as his analytical acuity and moral concern. Other projects, however, distracted him from making further significant contributions to the field. By the time Bell met Wight in 1951, Wight's only other substantial works of scholarship were three reference works on colonial constitutions and four brilliant but over-wrought essays in a forthcoming volume of the Chatham House Survey of International Affairs covering the war-years. ${ }^{17}$ His journalism, reviewing and extensive reading unquestionably slowed Wight's productivity, but so did two other things: his suspicion about the ways in which international relations was being approached, at that time, as an academic discipline and his exacting approach to the study of world politics.

Wight was sceptical about international relations when he accepted his Readership in 1949 and he was just as sceptical when he resigned it twelve years later, to take up a Chair in History. He disliked the social sciences in general, for what might today be considered peculiar reasons - he thought them dehumanising, but also a sign of a neo-pagan return to cyclic views of human destiny once banished by Christian historiography. ${ }^{18}$ His religious beliefs - he was a devout but intellectual Anglican - prevented him accepting that history could repeat itself, and thus prevented him from accepting that general 'laws' about social life could ever be determined. Only philosophy, literature and history were capable of capturing truths about human societies, Wight argued, and only these disciplines should underpin political thought and practice. ${ }^{19} \mathrm{In}$

14 On Manning, see Hidemi Suganami, 'C. A. W. Manning and the study of international relations', Review of International Studies, vol. 27, no. 1, 2001, pp. 91-107; and David Long, 'C. A. W. Manning and the discipline of international relations', The Round Table, vol. 95, no. 378, 2005, pp. 77-96, as well as Manning's own The Nature of International Society, Macmillan, London, 1962.

15 On these various details of Wight's early career and thought, see Hall, International Thought of Martin Wight, pp. 4-8.

16 Martin Wight, Power Politics, Looking Forward Pamphlet no. 8, Royal Institute of International Affairs, London, 1946.

17 See Martin Wight, The Development of the Legislative Council, 1606-1945, Faber \& Faber, London, 1946; The Gold Coast Legislative Council, Faber \& Faber, London, 1947; and British Colonial Constitutions 1947, Clarendon, Oxford, 1952; as well as his essays on 'Spain and 'Portugal', 'Switzerland, The Low Countries, and Scandinavia', 'Eastern Europe', 'Germany', and 'The Balance of Power', in AJ Toynbee and FT AshtonGwatkin (eds), Survey of International Affairs 1939-1946: The World in March 1939, Oxford University Press, London, 1952, pp. 138-150, pp. 151-165, pp. 206-292, pp. 293-365 and pp. 508-532.

18 See especially Martin Wight, 'History and Judgment: Butterfield, Niebuhr and the Technical History', The Frontier: A Christian Commentary on the Common Life, vol. 1, no. 8, 1950, p. 306.

19 As Wight wrote to his friend and erstwhile colleague at the LSE, Elie Kedourie, 'the teaching of International Relations ... convinced me that the only subjects which ought to be taught were philosophy, literature and history' (Wight to Kedourie, 21 November 1961, Wight MS 233 3/9, British Library of Political and Economic Sciences, London). 
his mind, the new social sciences were implicated in some way with not merely the secularisation of the West, which he lamented, but also the rise of new and more extreme forms of tyranny to any that had existed in the past. ${ }^{20}$

These beliefs conditioned Wight's approach to international relations. He was convinced that world politics required serious study, but unconvinced by the approaches used and the findings generated since the first chairs in the discipline were founded in the 1920s. Just after he first arrived at the LSE he proposed that the subject should have two poles: contemporary history and what he called, uncomfortably, but with hints of necessary deference to Manning's preferences, the 'Sociology of the International Community'. He rejected the objections of some professional historians to the study of contemporary history as palpably silly - they argued that it could not be written for lack of available sources, by which they meant official archives; Wight objected by saying-rightlythat medievalists work with far less. Some of the greatest history, he noted, was contemporary history: think of Thucydides, Clarendon or Churchill. But Wight argued that students of the field could not stop at contemporary history: they needed also to explore the relationships between 'powers', especially the 'certain kinds of habitual behaviour' which have 'crystallised in diplomacy'. ${ }^{21}$

How might this be done? Wight had been trained as a historian in the early 1930s, and at Oxford, where the History Faculty was notoriously conservative. In Cambridge, at the same time, historians had long been concerned with general and thematic history, and were then experimenting further, with social and economic history, with Marxist and sociological modes of analysis, and with the histories of science and medicine. At Oxford, however, the syllabus remained dominated by the political (primarily constitutional) history of England, studied by exhaustive investigation of mainly short periods. The principal concerns were ideas and institutions: the study of the changing ideas that informed the evolving institutions of English government.

Wight disliked the Oxford curriculum intensely, as he later recalled, ${ }^{22}$ but never fully escaped it. He shared Toynbee's belief that human societies only made sense to the observer if they were approached as wholes, but struggled to reconcile this belief in 'holism' with his continued insistence that the past must still be studied by the meticulous examination of primary sources. ${ }^{23}$ Understandably, this requirement placed too great a burden on Wight's own shoulders - he found it impossible to meet his own standards of scholarship and his output suffered as a consequence. He was able, however, to transmit some

\footnotetext{
20 See Hall, International Thought of Martin Wight, especially pp.6 5-85 (on 'The Crisis of Modern Politics').

21 Martin Wight, 'What is International Relations?' (1950), Wight MS 112, p. 17.

22 Martin Wight, 'Devising a History Syllabus', talk given at Reading, 28 February 1963, Wight MS 50.

23 On Wight's relationship with Toynbee's thought, see Ian Hall, 'Challenge and Response: The Lasting Engagement of Arnold J Toynbee and Martin Wight', International Relations, vol. 17, no. 3, 2003, pp. 389-404.
} 
elements of what he had inherited as an Oxford historian to his students. Above all, there was the insistence that politics is best explained in terms of ideas and institutions - specifically, the beliefs of agents and what we would now call the 'norms' of behaviour those beliefs generated - and best studied by looking at what politicians, diplomats, lawyers and other practitioners, say about those ideas and institutions.

This was Wight's vision of the study of international relations that Bell encountered in 1951 and that she carried forward, albeit with her own modifications. It combined the study of contemporary history and the institutions of international society — not the formal institutions, like the United Nations, but the informal ones that had arisen over time, like war or diplomacy, for managing the relations of political communities. It entailed the rigorous examination of the beliefs of decision-makers, the ways in which these beliefs shaped their perceptions of their circumstances, and manner in which these beliefs and perceptions shaped their changing practices. It was, in other words, an 'interpretive' approach to international theory which puts the beliefs of policy-actors and the traditions of thought that shape those beliefs centre-stage, as explanations for what occurs in international relations. It rejects the idea that systems and structures determine events and emphasises agency, contingency and contestability. ${ }^{24}$

\section{Beliefs, Conventions and Crises}

Under Wight's supervision, Bell's graduate work was an apprenticeship in this interpretive approach to international relations. She was set a project that involved the examination of a belief or set of beliefs and their effect on international practice in contemporary world politics: in her particular case, the idea of 'containment' and the ways in which it was translated into policy. Others who worked with Wight at around the same time were set similar tasks. For Hedley Bull, who arrived at the LSE as an Assistant Lecturer in 1955, soon after Bell's departure for Manchester, and began a PhD there under Wight's direction, it involved various aspects of Labour Party internationalism. ${ }^{25}$ For others, like Peter Lyon, it was 'neutralism' and 'nonalignment' ${ }^{26}$

For most of the first half of the 1950s, Bell balanced this work on containment at the LSE with other commitments at Chatham House, where she was employed

\footnotetext{
24 For further explorations of the interpretive approach, see Mark Bevir, Oliver Daddow and Ian Hall, 'Introduction: Interpreting British Foreign Policy', British Journal of Politics and International Relations, vol. 15, no. 2, 2013, pp. 163-174.

25 See Robert Ayson, Hedley Bull and the Accommodation of Power, Palgrave MacMillan, Basingstoke, 2012.

26 Peter Lyons, Neutralism, Leicester University Press, Leicester, 1963.
} 
as a research officer. Her duties included aiding the production of key projects, including Geoffrey Goodwin's ponderous Britain and the United Nations (1957), but she was also able to make a more substantial contribution of her own: the Survey of International Affairs for 1954 (1956). ${ }^{27}$ Bell recalls in her memoir that Chatham House provided the invaluable opportunity to meet and to speak to scholars and policy-makers in a relatively informal setting. But it also provided much-needed resources for the writing of contemporary history in the 1950s, not least the scrupulously-maintained press-cuttings archive that Toynbee had built up since the 1920s, which included material from newspapers and wire services across the world. Toynbee's inter-war Surveys were greatly dependent on these resources; Bell's volume is too. Apart from personal interactions with politicians and diplomats, these cuttings were the core source material of contemporary history until at least the latter part of the 1960s.

Bell used these kinds of materials not merely to determine factual information but also to gain insight into the beliefs of practitioners, a task that Wight insisted was crucial to the proper study of international relations. Beliefs dominate Bell's first major book, Negotiation from Strength (1962), ${ }^{28}$ which grew out of her graduate studies at the LSE. Her principal concern in the book is to tell the story of the rise and fall of a policy concept, 'negotiation from strength', which emerged in American foreign policy circles in 1950 as a possible alternative to 'containment'. But Bell also had another concern: to explore '[w] hat makes "an effective decision"'. 'How many people', she asked, 'have to feel what degree of conviction to turn aspiration into intention and intention into actual policy?' ${ }^{29}$ And there were other issues too. Bell was interested not just in the failure of a concept to be translated into an effective policy, but also the failure of that concept to disappear once its initial shortcoming had been detected.

These were big questions and Negotiation from Strength - arguably Bell's best book-delivered some intriguing answers. It shows how containment was replaced by a Western (mainly American) aspiration to be able to 'negotiate from strength' was related not just to changes in key personnel-principally from George Kennan to Paul Nitze, and from Harry Truman to John Foster Dulles - but to the relative popularity of differing accounts of Soviet strategy and diplomacy. Proponents of containment, Bell notes, believed that the "power struggle' between the US and USSR would only end with domestic political change within the Soviet Union; proponents of negotiation from strength

27 See Geoffrey Goodwin, Britain and the United Nations, Royal Institute of International Affairs and Oxford University Press, London, 1957; and Coral Bell, Survey of International Affairs for 1954, Royal Institute of International Affairs and Oxford University Press, London, 1956.

28 Coral Bell, Negotiation Negotiation from Strength: A Study in the Politics of Power, Chatto \& Windus, London, 1962, and Alfred A. Knopf, New York, 1963.

29 ibid., p. 12. 
assumed, by contrast, that 'diplomatic adjustment' was possible. ${ }^{30}$ During the course of the 1950s, she demonstrates, negotiation from strength came to replace containment as the dominant policy concept for the West, especially for American decision-makers. This occurred despite the hostility of John Foster Dulles, in particular, to diplomacy in general and to negotiation with the USSR in particular. ${ }^{31}$

Bell's book traces this story in minute detail and considerable insight into the beliefs of the key figures involved-without, it should be noted, any access to official documents. Her pen-portrait of Dulles and what she calls his 'theory of international politics' is especially perceptive and characteristically unemotive: she picks through his published works, interviews and profiles, and draws upon backgrounding interviews she carried out in Washington to provide a dispassionate assessment of his motives and his strategy. ${ }^{32}$ Bell argues that despite Dulles' position and extraordinary energy, he was overtaken by demands for negotiation as he worked to build American and allied strength. These came from Winston Churchill and indeed from the Soviets themselves, and from the general public. But the most powerful part of the book, arguably, is Bell's assessment of the perceptions of the participants in the negotiations, especially how they miscalculated and misunderstood their adversaries and failed to achieve any kind of deal. ${ }^{33}$

What, then, did Bell think we might learn from the rise and fall of negotiation from strength? In the conclusion, she reflected:

[I]t may be regarded ... as chiefly an illustration of how two competing alliances may be bound to the policy-purposes of their most vulnerable members, or ... as an illustration of the progress of a policy through stages of ambition, distraction, approximation and supersession, as a study in cross-purposes and the political uses of illusion, an example of how wide the gap may be between declared policy and what is actually done, and of how much more important in politics than intention is what Fisher called the play of the contingent and the unforeseen. ${ }^{34}$

This is a distinctively 'interpretivist' passage and a subtle one. Bell suggested that negotiation from strength might be regarded as little more than an 'official myth' or a 'harmless necessary public-relations-man's phrase' - a kind of noble lie that comforts democratic electorates but means little. ${ }^{35}$ But to dismiss it that way would be to ignore the ways in which the concept clearly shaped

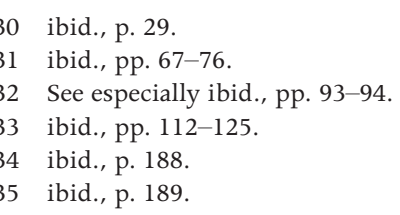


policy, albeit a failed one, and shaped expectations of what might be possible and what might eventuate. As Bell argued later, she was convinced that '[i]nternational politics proceeds essentially on nothing more substantial than a set of expectations: expectations as to where power will prove to be and how it will be used'. ${ }^{36}$

Bell's subsequent work - with the major exception of The Diplomacy of Détente, which concentrates on the beliefs and behaviour of one man above all: Henry Kissinger ${ }^{37}$ - focussed less on beliefs and more on what she called 'conventions'. We might call them social institutions, perhaps laws (in a social scientific sense), or even just norms. What Bell meant by conventions was just what it conveys in ordinary parlance: expected or understood signals (as in the conventions of bridge), or rules of behaviour with no particular moral or legal backing, sanctioned chiefly by prudence and custom, and stemming from a particular society'. ${ }^{38}$ Here again, Bell moved in a Wightean universe, but in parts Wight himself neglected. He had argued that international society was defined and ordered by its 'institutions' - not formal institutions, like the UN, but informal bundles of beliefs, expectations, rules and indeed conventions of behaviour. Borrowing from contemporary social anthropology, consciously or not, Wight cast war, diplomacy, international law, great powers and the balance of powers as social 'institutions' in which there were assumptions, acceptances and anticipations of particular kinds of behaviour by practitioners. ${ }^{39}$

Bell narrowed her concerns merely to conventions and especially to what she termed, in the book of the same name, The Conventions of Crisis (1971). ${ }^{40}$ Her interest was in the evolving conventions that existed during crisesexpectations around behaviour and conduct - focussing attention once more upon the beliefs of practitioners as the motive forces of international relations. Crisis management, she argued, is 'learned behaviour' which may or may not be 'institutionalised' - by which she meant learned, taught and re-learned within communities of practitioners. ${ }^{41}$ The conventions that might be used, learned and taught varied: they could be forms of signalling, some crude and some highly subtle, military, economic, political or diplomatic, or certain techniques,

\footnotetext{
36 Coral Bell, 'Local Threats and the Central Balance', in her edited Academic Studies and International Politics: Papers of a Conference held at the Australian National University, June 1981, Canberra Studies in World Affairs, The Australian National University, no. 6, 1982, p. 151.

37 Coral Bell, The Diplomacy of Détente: The Kissinger Era, Martin Robertson, London, 1977.

38 Coral Bell, 'Crisis Diplomacy', in Laurence Martin, ed., Strategic Thought in a Nuclear Age, Heinemann, 1979, London, p. 158.

39 See especially Wight's Power Politics.

40 Coral Bell, The Conventions of Crisis: A Study in Diplomatic Management, Oxford University Press for the Royal Institute of International Affairs, London and New York, 1971.

41 ibid., p. 25.
} 
like the 'creative use of ambiguity' ${ }^{42}$ And crucially, in Bell's world, they come into play when self-consciously and deliberately selected by individual agents confronted with changing sets of circumstances.

In this way, Bell succeeded in developing Wight's interpretive approach, with its emphasis on agents and beliefs, but succeeded not just in describing the emergence of concepts and policies, but also in explaining significant changes in the everyday practices of the society of states. Other thinkers influenced by the early English School struggled to get this balance right. Bull, for example, in his The Anarchical Society, never got into sufficient detail to really explain how that society and its institutions were changing and why. ${ }^{43}$ Bell's dogged focus on crisis management, by contrast, tells us a great deal more about what is evolving and what is perennial, giving her the platform for later works, like $A$ World Out of Balance, ${ }^{44}$ that take the 'long view' of contemporary events and generate important arguments about the drivers of change in international relations.

\section{Conclusion}

Bell's other perennial concern-apart from conventions - was 'power politics' or, more precisely, because that term has become synonymous with international relations, the politics of power. She was concerned with how power was conceived and especially how it was used, principally by great powers. But for Bell 'power' did not mean the material capabilities of actors. It was a much more complex concept. Power was something perceived or misperceived, calculated or miscalculated, not innate in a set of resources or weapons. Power was relational: it implied to Bell the capacity of one party to influence or even control the actions of others. Power could be wielded in crude ways, by making military threats or imposing economic sanctions, by forcing others to bend to one's will. But equally power could consist of the ability to seize and hold an agenda, to articulate a set of ideas and thereby to force others to justify or even modify their behaviour. Power might flow from a concerted effort to utilise an institution or to mobilise opinion-something which even those who lack material military or economic power can do.

One of Bell's earliest articles dealt with these kinds of uses of power by the hitherto powerless. Her 'The United Nations and the West' (1953), published in the Chatham House journal International Affairs, bears like her other work of

\footnotetext{
42 ibid., p. 74.

43 Hedley Bull, The Anarchical Society: A Study of Order in World Politics, 2nd edn, Macmillan, London, 1995.

44 Coral Bell, A World Out of Balance: American Ascendancy and International Politics in the 21st Century, Longueville Books, Double Bay, 2003.
} 
that period the distinct signs of the influence of Wight in its composition and its message, ${ }^{45}$ but it is also revealing about Bell's own views. She opens with the observation - commonplace in British international thought in the immediate post-war years - that the Second World War and its aftermath had brought about the 'contraction of Europe' after two hundred years of expansion and the 'eclipse of Europe in Power-terms' not just by the United States and the Soviet Union, but by anti-colonial forces. ${ }^{46}$ The latter, Bell acknowledged, might be relatively weak in material terms, but they are irresistible politically:

Political control rests on elements of consent and coercion, and the belief that the controlling Power can exert force of a decisive kind tends to reduce to the minimum the amount actually needed. Conversely, where doubt is thrown upon the effective power available to the controlling nations, as in the case of the defeat of the European Powers in South East Asia by Japan, forces inimical to that control are encouraged, and the re-imposition of authority is rendered difficult or impossible. ${ }^{47}$

Bell's concern in this article, however, was not so much with challenges to European authority on what used to be called the colonial periphery, but with the ways in which those 'forces inimical to control' mobilised themselves at the UN to build and project power.

Bell's power politics was a politics with agency where the materially-rich did not, as many other realists might argue, necessarily prevail. International politics were to her an arena in which agents manoeuvred, making good or bad use of both the intellectual and material resources they had at their disposal. For that reason, the beliefs of agents mattered, because they informed the ways in which they approached predicaments, deployed what resources they had at their disposal, and shaped policies to achieve their objectives. What Bell presented in her international thought, in other words, was a vision of international relations that was both human and humane.

45 For a point of comparison, see Martin Wight's 'The Power Struggle at the United Nations', Proceedings of the Institute of World Affairs, 33rd session, University of Southern California, Los Angeles, 1956, pp. 247-259. 46 Coral Bell, 'The United Nations and the West', International Affairs, vol. 29, no. 4, 1953, pp. 464-465.

47 ibid., p. 465. 
This text taken from Power and International Relations:

Essays in honour of Coral Bell, edited by Desmond Ball and Sheryn Lee, published 2014 by ANU Press, The Australian National University, Canberra, Australia. 